\title{
Homeostasis indicators in cows before ostrus synchronization and their influence on the fertilization rate
}

\author{
A. Y. Kraevsky' ${ }^{1}$, V. M. Sokoluk², O. M. Chekan ${ }^{1}$ M. O. Travetsky' ${ }^{1}$ I. P. Ligomina² \\ 'Sumy National Agrarian University, 160 Herasym Kondratiev St., 40021, Sumy, Ukraine \\ ${ }^{2}$ Zhytomyr National Agroecological University, Zhytomyr, Staryi Blvd., 7, Zhytomyr, 10008, Ukraine \\ *Corresponding authorE-mail:kay57@ukr.net \\ Received: 06.10.2020. Accepted 25.11.2020
}

The relationship between cows' homeostasis in the early postpartum period and the effectiveness of fertilization during lactation was analyzed. There were found a decrease in vitamin E to $3.9 \pm 0.16 \mu \mathrm{g} / \mathrm{ml}$, an increase in urea to $6.4 \pm 0.24 \mathrm{mmol} / \mathrm{l}$, alkaline phosphatase to $120.7 \pm 5.24 \mathrm{U} / \mathrm{l}$, urea nitrogen to $12.3 \pm 0.46 \mathrm{mg} / 100 \mathrm{ml}$ and aspartate aminotransferase up to 137.8 $\pm 10.45 \mathrm{IU} / \mathrm{l}$ in cows that were culled or left infertile throughout the lactation period. These data may indicate an overload of the compensatory reactions of the enzymatic and oxidative systems of the liver in cows with defective rumen digestion. There was also persistent hyperproteinemia with compensated oxidative stress due to a decrease in zinc and vitamin $\mathrm{E}$ content in cows fertilized 60-120 days compared with those fertilized six months and later after calving.

Key words: cows, postpartum period, homeostasis, fertilization, culling, time of fertilization, productivity

\section{Introduction}

It is generally accepted that obtaining one calf from each cow during the year is physiologically and economically justified, which ensures high profitability of dairy farming in general. Achieving such indicators in dairy farming is possible provided that all cows are fertilized 60-120 days after calving. According to a number of researchers (Saha et al., 2016; Travetsky, 2016) recovery of estrus in cows within 60 days after calving can range from 7 up to 50\% depending on the breed, fattening of animals, their productivity and many other environmental (feeding, housing conditions, indoor microclimate, seasons, herd management) factors (Bomko et al., 2018; Kulyaba et al., 2020; Borshch et al., 2020; Grymak et al., 2020; Mazur et al., 2020; Slivinska et al., 2020).

Fertility of cows during 120 days of lactation range from 7 to $57 \%$, while at the first insemination this figure was from 27 to $63 \%$ (Bova et al., 2014; Saha et al., 2016).

Today, it is well analyzed and generally accepted that in highly productive dairy cows before, during and after calving there are hormonal and metabolic changes caused by the completion of fetal development, birth and lactation. These changes are manifested by negative energy balance, deficiency of proteins, minerals and vitamins (Osorio et al., 2013; Abuelo et al, 2019). As a result, metabolic stress develops during and immediately after calving periods, which leads to a decrease in immunity, and subsequently - to the development of inflammatory processes and impaired reproductive function (Chastant \& Saint-Dizier, 2019; Sahoo, 2020).

In order to prevent metabolic stress in many farms are successfully used a variety of feed additives before and after calving. However, due attention to the state of homeostasis before and during the restoration of reproductive cyclicity and / or synchronization of estrus, ie, at 30-60 days of lactation or during the stage of the highest productivity is not paid. At the same time, the level of cows fertility of is correlated with the state of animal homeostasis.

The research aim was to establish the relationship between individual indicators that characterize. cows' homeostasis during 30-60 days after calving and their reproductive function during lactation.

To achieve this goal, we set several taks:

To determine homeostasis indicators of cows during 30-60 days after calving and to analyze them depending on reproductive function during lactation. To analyze the state of cows' homeostasis during 30-60 days after calving, depending on fertilization rate before 117 and after 171 days of lactation. 


\section{Materials and Methods}

The material for the research was high-yielding dairy cows with an annual milk production of $7200 \mathrm{~kg}$.

Blood samples for biochemical studies were taken in cows before morning feeding during 30-60 days after calving. The blood was taken from the caudal vein in accordance with the rules for biological material collection. Serum prepared from the selected blood samples was frozen at a temperature of $-20^{\circ} \mathrm{C}$ and stored in this state until the time of the study.

In serum samples on an automatic biochemical analyzer Miura-200 (Italy) creates the content of total protein (with biuret reagent), albumin (with bromocres green), creatinine (for rapid development of creatinine-picrate complex in Jaffa reactions), glucose, with reaction with arsenase III) using ready-made kits of reagents produced by Cormay (Poland), urea (enzymatic for Berthelot's reaction) - with a set of reagents Spinreakt (Spain), inorganic phosphorus (with ammonium molybdate) - with a set of Dialab (methanedium), potassium with sodium tetraphenylborate) and Iron (by reaction with ferrosine) - with a set of HTI (USA).

Indicators of mineral-electrolyte metabolism there were studied the content of sodium with magnesium-uranyl acetate (Human, Germany) and magnesium - colometric method with kalmagite (HTI, USA). Evaluation of the reaction results was performed on a semi-automatic biochemical analyzer Humalazer 3000 (Human, Germany).

In order to assess the colloidal stability of serum proteins used Veltman's test. The obtained data were expressed in $\mathrm{ml}$ of calcium chloride solution - what amount of the solution have to be added for protein precipitation to be observed.

The serum activity of transaminases (ALT and AST) was determined by the kinetic method with reagents produced by Spinreakt (Spain), and alkaline phosphatase - kinetically (by increasing levels of 4-nitrophenol) using kits provided by Cormay (Poland). An automatic analyzer Miura-200 (Italy) was used for the research.

The concentration of lipoproteins was determined by the turbidimetric method according to Burstein-Samai, the carotene content - spectrophotometrically in hexane extracts of blood serum after pre-precipitation of proteins with ethyl alcohol (the optical density was measured using a spectrophotometer Ulab-2 (China)).

Vitamins $A$ and $E$ in the serum were determined by high performance liquid chromatography using an Agilent Technologies 1260 Infinity chromatograph from Agilent Technologies. Separation was performed on a C18 column using the mobile phase acetonitrile-propanol-water, followed by spectrophotometric detection at a wavelength for vitamin $\mathrm{A}$ of $328 \mathrm{~nm}$, for vitamin E $286 \mathrm{~nm}$. The flow rate was $0.75 \mathrm{ml} / \mathrm{min}$. Honeywell (USA) and Carlo Erba (Italy) reagents were used to make the components of the solvent system.

The content of copper and zinc in blood serum was determined on an atomic absorption spectrophotometer Selmi FCM 115 (Ukraine) with flame atomization by the intensity of absorption characteristic of each chemical element of the spectral lines. Globulin content, protein ratio, urea nitrogen and de Ritis index were determined by calculation.

The obtained digital material was processed by methods of variation statistics using SPSS Data editor 17.0 version.

Further analysis of the studied homeostasis indicators was performed depending on the physiological condition of cows throughout the lactation period and the studied groups were formed accordingly. The first group included cows that became pregnant during lactation. The second group consisted of infertile animals and those that were culled during this period.

At the next stage of the analysis, each group of pregnant cows was divided into two subgroups depending on the duration of the period from calving to fertilization. The first subgroup included cows that became pregnant before 117, the second - after 171 days of lactation. Full homeostasis status was evaluated in both subgroups.

\section{Results}

During biochemical blood tests of cows 30-60 days after calving, the level of total protein in animals that became pregnant (first group, 13 goals) to $190.2 \pm 30.51$ days and in infertile cows or those that were culled (second group, 6 goals.) Was at the upper limit of the reference values and was, respectively, $85.7 \pm 1.52$ and $86.0 \pm 2.58 \mathrm{~g} / \mathrm{l}$.

In the first group of animals, its structure consisted of $43.2 \%$ of albumins $(37.0 \pm 0.82 \mathrm{~g} / \mathrm{l})$ and $56.8 \%$ of globulins $(48.7 \pm 1.75$ $\mathrm{g} / \mathrm{l})$. In cows of the second group, these figures were 42.1 and $57.9 \%$ or $36.2 \pm 1.4$ and $49.8 \pm 2.06 \mathrm{~g} / \mathrm{l}$, the protein coefficient ranged within the appropriate limits and was $0.76 \pm 0.037$ in cows of the first group and $0.73 \pm 0.062$ units animals of the second group, indicating an intense course of protein metabolism in both groups of cows.

At the same time, further analysis of the results of studies on the state of homeostasis depending on the duration of the period before insemination of cows showed that within 4 months after calving fertilized (5 goals) $38.5 \%$ of animals were classified in the first subgroup. The remaining cows ( 8 heads) $61.5 \%$ were inseminated after 171 days of lactation, they formed the second subgroup. The period from calving to fertilization in the first subgroup averaged $94.2 \pm 9.33$ days (71-117), in the second 250.3 \pm 34.98 days. Protein metabolism in cows of the first subgroup was characterized by an increased content of total protein in the blood 1.1 times $(p \leq 0.001)$ compared with the second subgroup of animals fertilized after 171 days of lactation. This concentration of total blood protein and its metabolism in cows of the first subgroup were due to increased levels of globulins, the content of which exceeded their level in cows of the second subgroup by 1.2 times $(p \leq 0.01)$, which caused a tendency to decrease the protein ratio by 1,24 times $(p \leq 0.05)$ from $0.83 \pm 0.037$ to $0.67 \pm 0.063$ units. 
Table 1. Indicators of homeostasis in cows for 30-60 days after calving, depending on the state of reproductive function during lactation

\begin{tabular}{|c|c|c|}
\hline Indicators & In-calf, $n=13$ & Infertile, n=6 \\
\hline Total protein $\mathrm{g} / \mathrm{l}$ & $85.7 \pm 1.52$ & $86.0 \pm 2.58$ \\
\hline Albumins $\mathrm{g} / \mathrm{l}$ & $37.0 \pm 0.82$ & $36.2 \pm 1.4$ \\
\hline Globulins g/l & $48.7 \pm 1.75$ & $49.8 \pm 2.06$ \\
\hline Protein coefficient, units & $0.76 \pm 0.037$ & $0.73 \pm 0.062$ \\
\hline $\mathrm{ALT}, \mathrm{U} / \mathrm{I}$ & $32.7 \pm 1.03$ & $32.0 \pm 1.0$ \\
\hline AST, Od/I & $100.7 \pm 6.31$ & $137.8 \pm 10.45^{* *}$ \\
\hline De Ritis coefficient, units & $3.1 \pm 0.19$ & $4.4 \pm 0.44^{*}$ \\
\hline Veltman's test, unit. & $0.25 \pm 0.018$ & $0.28 \pm 0.048$ \\
\hline Alkaline phosphatase, U/l & $103.6 \pm 4.62$ & $120.7 \pm 5.24^{*}$ \\
\hline Urea, $\mathrm{mmol} / \mathrm{l}$ & $5.4 \pm 0.17$ & $6.4 \pm 0.24 * \star$ \\
\hline Urea nitrogen, mg/100 ml & $10.3 \pm 0.34$ & $12.3 \pm 0.46^{\star \star}$ \\
\hline Glucose, $\mathrm{mmol} / \mathrm{l}$ & $2.45 \pm 0.077$ & $2.68 \pm 0.101^{\mathrm{a}}$ \\
\hline Total lipoproteins, mg/100 ml & $1004.5 \pm 74.03$ & $988.7 \pm 118.92$ \\
\hline Carotene, $\mu \mathrm{g} / 100 \mathrm{ml}$ & $429.7 \pm 40.61$ & $442.8 \pm 89.4$ \\
\hline Vitamin $\mathrm{A}, \mu \mathrm{g} / 100 \mathrm{ml}$ & $28.6 \pm 1.94$ & $26.5 \pm 3.88$ \\
\hline Vitamin $\mathrm{E}, \mu \mathrm{g} / \mathrm{ml}$ & $4.4 \pm 0.18$ & $3.9 \pm 0.16^{*}$ \\
\hline Total calcium, mmol/l & $1.85 \pm 0.022$ & $1.87 \pm 0.067$ \\
\hline Inorganic phosphorus, mmol// & $1.9 \pm 0.06$ & $2.0 \pm 0.09$ \\
\hline $\mathrm{Ca} / \mathrm{P}$ & $1.0 \pm 0.04$ & $0.9 \pm 0.04$ \\
\hline Copper, $\mu \mathrm{g} / 100 \mathrm{ml}$ & $75.99 \pm 3.124$ & $83.3 \pm 2.66^{a}$ \\
\hline Zinc, $\mu \mathrm{g} / 100 \mathrm{ml}$ & $69.9 \pm 3.68$ & $70.6 \pm 7.6$ \\
\hline Magnesium, mmol/l & $1.4 \pm 0.06$ & $1.3 \pm 0.07$ \\
\hline Potassium, $\mathrm{mmol} / \mathrm{l}$ & $4.7 \pm 0.4$ & $4.9 \pm 0.4$ \\
\hline Sodium, mmol/liter & $135.2 \pm 5.81$ & $118.6 \pm 8.66$ \\
\hline Iron, $\mu \mathrm{mol} / \mathrm{I}$ & $24.2 \pm 2.02$ & $20.4 \pm 0.81^{a}$ \\
\hline
\end{tabular}

Notes. $^{a}$ - tendency to increase or decrease; ${ }^{*}-p \leq 0.05 ;{ }^{* *}-p \leq 0.01$ relative to cows of the first group.

According to Veltman's test, the course of the pathological process, most often the liver, is determined. Its numerical value in both groups and subgroups of cows indicates a chronic course of the pathological process of the liver. In addition, in the blood of cows of both groups there was increased activity of liver enzymes ALT, AST and LF. However, if ALT activity did not differ significantly between groups of cows, the activity of AST and LF was probably higher in cows of the second group, which remained infertile or were rejected $1.37(p \leq 0.01)$ and 1.17 times 0.05$)$, respectively. The increase in ACT activity in cows of the second group caused an increase in the de Ritis coefficient in these animals by 1.42 times ( $p \leq 0.05)$ relative to animals of the first group from $3.1 \pm 0.19$ units. up to $4.4 \pm 0.44$ units.

Table 2. Indicators of homeostasis in pregnant cows during fertilization for 60-120 days and more than 171 days after calving

\begin{tabular}{|c|c|c|}
\hline Indicators & Fertilized up to 120 days $n=5$ & Fertilized after 171 days $n=8$ \\
\hline Total protein g/l & $91.0 \pm 1.58$ & $82.4 \pm 1.21 * * *$ \\
\hline Albumins $g / l$ & $36.4 \pm 1.44$ & $37.4 \pm 1.05$ \\
\hline Globulins g/l & $54.6 \pm 2.71$ & $45.0 \pm 0.91 * *$ \\
\hline Protein coefficient, units & $0.67 \pm 0.063$ & $0.83 \pm 0.037$ \\
\hline $\mathrm{ALT}, \mathrm{U} / \mathrm{I}$ & $30.6 \pm 1.63$ & $34.0 \pm 1.17$ \\
\hline AST, Od/I & $110.4 \pm 7.71$ & $94.6 \pm 3.26^{a}$ \\
\hline De Ritis coefficient, units & $3.6 \pm 0.36$ & $2.8 \pm 0.15^{\mathrm{a}}$ \\
\hline Veltman's test, unit. & $0.24 \pm 0.04$ & $0.25 \pm 0.02$ \\
\hline Alkaline phosphatase, U/l & $95.9 \pm 4.76$ & $108.4 \pm 6.55$ \\
\hline Urea, $\mathrm{mmol} / \mathrm{l}$ & $5.4 \pm 0.33$ & $5.36 \pm 0.198$ \\
\hline Urea nitrogen, mg/100 ml & $10.32 \pm 0.621$ & $10.2 \pm 0.43$ \\
\hline Glucose, $\mathrm{mmol} / \mathrm{l}$ & $2.5 \pm 0.17$ & $2.4 \pm 0.08$ \\
\hline Total lipoproteins, mg/100 ml & $1141 \pm 175.6$ & $919.1 \pm 39.39$ \\
\hline Carotene, $\mu \mathrm{g} / 100 \mathrm{ml}$ & $486.4 \pm 56.91$ & $394.1 \pm 54.5$ \\
\hline Vitamin $A, \mu g / 100 \mathrm{ml}$ & $28.0 \pm 4.76$ & $28.9 \pm 1.53$ \\
\hline Vitamin $E, \mu g / m l$ & $4.1 \pm 0.042$ & $4.6 \pm 0.27^{a}$ \\
\hline Total calcium, mmol/l & $1.82 \pm 0.04$ & $1.88 \pm 0.025$ \\
\hline Inorganic phosphorus, $\mathrm{mmol} / \mathrm{I}$ & $1.7 \pm 0.09$ & $2.0 \pm 0.05^{\star}$ \\
\hline $\mathrm{Ca} / \mathrm{P}$ & $1.1 \pm 0.07$ & $0.95 \pm 0.03^{\mathrm{a}}$ \\
\hline Copper, $\mu \mathrm{g} / 100 \mathrm{ml}$ & $74.6 \pm 5.42$ & $76.8 \pm 4.05$ \\
\hline Zinc, $\mu g / 100 \mathrm{ml}$ & $59.0 \pm 7.26$ & $76.75 \pm 1.27 *$ \\
\hline Magnesium, mmol/l & $1.48 \pm 0.092$ & $1.41 \pm 0.0766$ \\
\hline Potassium, $\mathrm{mmol} / \mathrm{l}$ & $4.4 \pm 0.42$ & $4.9 \pm 0.56$ \\
\hline Sodium, mmol/liter & $135.9 \pm 11.5$ & $134.8 \pm 6.84$ \\
\hline Iron, $\mu \mathrm{mol} / \mathrm{I}$ & $25.86 \pm 4.41$ & $23.2 \pm 2.0$ \\
\hline
\end{tabular}

Note: ${ }^{a}$ - tendency to increase or decrease; ${ }^{*}-p \leq 0.05 ; * \star-p \leq 0.01 ; * \star \star-p \leq 0.001$ relative to cows of the first group. 
Analysis of enzyme activity depending on the duration of the lactation period before fertilization showed that it probably did not differ between subgroups of cows. However, in animals of the first subgroup there was a tendency to increase the activity of ACT and the de Ritis coefficient $(p \leq 0.072)$ and $(p \leq 0.071)$ relative to cows of the second subgroup from $2.8 \pm 0.15$ to $3.6 \pm 0.36$ units, and LF activity, on the contrary, tended to increase in animals of the second subgroup.

It should be noted that protein metabolism depends on the state of rumen digestion, which is determined by the content of urea and nitrogen in the blood. In particular, the content of urea and its nitrogen in the blood of cows of the second group was 1.19 times $(p \leq 0.01)$ higher than in animals of the first group. This may indicate a violation of the processes of cicatricial digestion and, as a consequence, protein metabolism in cows that have remained infertile or have been culled. However, the blood glucose level of the second group of cows had a slight tendency to increase.

Analysis of cicatricial digestion in cows depending on the duration of lactation before fertilization showed that the content of urea and nitrogen between subgroups of cows probably did not differ, but was equal to the upper limit of the reference values, indicating intense cicatricial digestion. Glucose content, which in ruminants depends on the state of rumen digestion and the intensity of gluconeogenesis, in the blood of cows of both subgroups probably did not differ and was $2.5 \pm 0.17 \mathrm{mmol} / \mathrm{l}$ - in the first and $2.4 \pm 0.08 \mathrm{mmol} / \mathrm{l}$ - in the second subgroups.

The content of total lipoproteins between groups and subgroups of cows probably did not differ.

Vitamin metabolism was characterized by an increased content of vitamin $E$ by $12.8 \%(p \leq 0.01)$ in cows, which later became pregnant. It should be noted that in these animals the content of vitamin $E$ in the blood differed slightly depending on the length of the period before fertilization after calving. Thus, in cows fertilized after 171 days of lactation there was a tendency to increase it relative to the first subgroup of animals. The level of carotene and vitamin A between groups and subgroups of cows probably did not differ.

Mineral metabolism was characterized by a low content of total calcium in the blood of both groups of cows and tended to increase the level of copper in animals of the second group and iron in the first.

Mineral metabolism in both subgroups of cows occurred due to hypocalcemia and increased phosphorus content in the blood of animals of the second subgroup 1.18 times $(p \leq 0.05)$ relative to cows of the first subgroup, which caused a tendency to decrease the $\mathrm{Ca} / \mathrm{P}$ ratio.

The results of studies of the content in the blood of animals of both subgroups of all other micro- and macroelements probably did not differ, except for Zinc, the level of which in the blood of animals of the second subgroup was 1.3 times higher $(p \leq 0.05)$. At the same time, cows fertilized in the sixth month of lactation and 30-60 days after calving have a lower level of total protein due to lower globulin content against the background of a tendency to decrease ACT activity and de Ritis coefficient and a slight increase in LF activity. An increase in the concentration of inorganic phosphorus was also found, which leads to a violation of the ratio of calcium to phosphorus relative to these indicators of cows that became pregnant during the third and fourth months of lactation. In addition, cows that became pregnant three to four months after calving have a tendency to decrease in vitamin E and a probable decrease in zinc content.

\section{Discussion}

Serum proteins are important indicators of animal health (Bobbo et al., 2017), therefore according to changes in their concentration, the course of physiological (Tóthová et al., 2018) and pathological (Tóthová et al., 2017). 14 proteins expressed by various genes that are closely related to the development of ovarian dysfunction at the beginning of lactation in dairy cows (Zhao et al., 2019).

The results of our studies indicate a high level of total protein in the blood of cows of both groups and in a subgroup of animals fertilized up to 120 days after calving, due to its globulin fraction and lower A / G ratio coincide with the data of some authors who report similar growth dynamics the amount of total protein within 6 weeks after calving (Tóthová et al., 2018). However, in other studies, the authors note that a high concentration of total protein in the blood of cows, due to an increase in globulin content with decreasing A/G ratio, may be observed in the development of inflammatory processes of the uterus, breast, limbs (Tóthová et al., 2018; Zhao et al., 2019). The role of the liver in protein metabolism is well known (Cui et al., 2019). Morphological and physiological changes in the liver associated with the development of a negative energy balance in the transition period can lead to its fatty degeneration, characterized by increased enzyme activity (Roy et al., 2011).

Therefore, increased activity of AST and LF and increased de Ritis coefficient in the group of infertile and cull cows should be considered as a sign of the development of biochemical syndrome of hepatocyte cytolysis, which causes dysfunction of other body systems, including reproductive. A number of researchers (Wathes et al., 2007) indicate the increased activity of ACT against the background of low concentration of glucose and calcium in the blood of cows. However, according to the results of our studies, the concentration of glucose in the blood of the second group of cows tended to increase relative to animals that became pregnant.

It is generally accepted that feeding cows on diets high in protein increases the milk productivity of cows, but reduces their reproductive function. One of the factors of this state of reproductive function in cows is the accumulation of urea in biological fluids (Raboisson et al., 2017). A similar view of the high or low concentration of urea in the blood of dairy cows and its effect on reducing their fertility is expressed by some researchers (Cheng et al., 2015). At the same time (Drift et al., 2012; Kowsar et al., 2018) hypothesize that high concentrations of urea before fertilization are more harmful than after it. In addition, a number of researchers see that the harmful effects of urea on reproductive function in dairy cows are indirectly due to metabolic disorders in the endometrium, especially lipid, as well as reduced immune protection of the uterus and the release of proinflammatory cytokines (Bindari et al., 2013). Also, the increase in urea in biological fluids can have a detrimental effect on both oocytes and early embryos (Pontes et al., 2015). It is obvious that high urea levels are a consequence of increased ammonia 
production in the rumen due to high levels of protein nutrition in cows or in body tissues due to the development of negative energy balance and breakdown of tissue proteins, in particular myofibrillar (Hussein \& Staufenbiel, 2012). In both cases, this causes a parallel with the level of urea increase in the content of ammonia in the blood, which probably has a negative impact on the processes of energy metabolism in the tissues of the genitals and directly on the oocytes.

Thus, infertility of cows of the second group can be explained by high content of urea in blood. In addition, low levels of vitamin $E$ in infertile cows indicate the development of oxidative stress in these animals. After all, it is known that vitamin $E$ functions as an intracellular non-enzymatic antioxidant that converts free reactive oxygen and lipid hydroperoxides into non-reactive forms, thus maintaining the integrity of membrane phospholipids (Drift et al., 2012). Increased fertility of cows and reduced embryonic mortality from vitamin E injections have been reported by a number of researchers (Pontes et al., 2015). The tendency to increase copper levels in infertile cows can be explained by the destruction of hepatocytes, as indicated by increased ACT activity in these animals. In addition, a number of researchers (Hussein \& Staufenbiel, 2012) believe that such an increase in blood copper is secondary and can be explained by increased activity of ceruloplasmin, as it contains more than $95 \%$ of blood copper. Ceruloplasmin is considered one of the proteins of the acute phase of inflammation, so its increased level is found in the blood of cows with inflammatory processes. In addition, ceruloplasmin plays an important role in iron metabolism (Gammoh \& Rink, 2017), which can explain the tendency to decrease in the blood of cows of the second group (Hussein et al., 2019).

Probably lower levels of zinc in the blood of cows of the first subgroup can be explained by increased oxidative stress, as indicated by the tendency to reduce the content of vitamin E (Liu et al., 2014; Pontes et al., 2015; Jarosz et al., 2017; Gammoh \& Rink, 2017) zinc deficiency may increase the formation of proteins of the acute phase of inflammation . Indirect evidence of this phenomenon in our studies may be the high concentration of total protein due to the globulin fraction in cows of the first subgroup.

Probably the higher level of phosphorus in the blood of cows of the second subgroup can be explained by the destruction of membrane phospholipids and the release of phosphorus due to oxidative stress of these animals, or this element from the bones to compensate for hypocalcemia, as evidenced by an increase in alkaline phosphatase activity in the serum. The content of all other minerals probably did not differ between groups and subgroups of cows (Drift et al., 2012).

\section{Conclusions}

Thus, in cows that remained infertile or were culled during lactation for 30-60 days after calving, there is hyperenzymemia, high urea, and a decrease in the concentration of vitamin E. This state of homeostasis indicates a strained functioning of the enzymatic and oxidative systems of the liver on the background of scarring. digestion, as evidenced by a tendency to increase glucose and copper levels and lower iron in the blood.

At the same time, in cows fertilized in the third or fourth month of lactation for 30-60 days after calving, there is hyperproteinemia due to hyperglobunaemia and a tendency to divergent changes in enzyme activity, which does not violate the ratio of calcium to phosphorus and compensates for oxidative stress by reducing zinc and vitamin E for cows that became pregnant at a later stage of lactation.

Given the indicators indicating rumen digestion in infertile and culled cows and hyperprotenemia and hyperglobunaemia in animals that became pregnant at the optimal time after calving and phosphorus metabolism in cows bred at a later stage of lactation, further research should be devoted to proteins of the globulin fraction depending on the state of scar digestion and mineral metabolism.

\section{Conflict of interest}

The authors declare that they have no conflict of interest.

\section{References}

Abuelo, A., Hernández, J., Benedito, J. L., \& Castillo, C. (2019). Redox Biology in Transition Periods of Dairy Cattle: Role in the Health of Periparturient and Neonatal Animals. Antioxidants (Basel, Switzerland), 8(1), 20. doi: 10.3390/antiox8010020

Bindari, Y. R., Shrestha, S., Shrestha, N., \& Gaire, T. (2013). Effects of nutrition on reproduction-a review. Adv Appl Sci Res, 4, $421-429$.

Bobbo, T., Fiore, E., Gianesella, M., Morgante, M., Gallo, L., Ruegg, P., ... Cecchinato, A. (2017). Variation in blood serum proteins and association with somatic cell count in dairy cattle from multi-breed herds. Animal, 11(12), 2309-2319. doi: 10.1017/S1751731117001227

Bomko, V., Kropyvka, Yu., Bomko, L., Chernyuk, S., Kropyvka, S., Gutyj, B. (2018). Effect of mixed ligand complexes of Zinc, Manganese, and Cobalt on the Manganese balance in high-yielding cows during first 100-days lactation. Ukrainian Journal of Ecology, 8(1), 420-425. doi: 10.15421/2018_230

Borshch, O. O., Gutyj, B. V., Sobolev, O. I., Borshch, O. V., Ruban, S. Yu., Bilkevich, V. V., Dutka, V. R., Chernenko, O. M., Zhelavskyi, M. M., \& Nahirniak, T. (2020). Adaptation strategy of different cow genotypes to the voluntary milking system. Ukrainian Journal of Ecology, 10(1), 145-150. doi: 10.15421/2020_23

Bova, T. L., Chiavaccini, L., Cline, G. F., Hart, C. G., Matheny, K., Muth, A. M., Voelz, B. E., Kesler, D., \& Memili, E. (2014). Environmental stressors influencing hormones and systems physiology in cattle. Reproductive Biology and Endocrinology, 12, 58. doi: 10.1186/1477-7827-12-58

Chastant, S., \& Saint-Dizier, M. (2019). Inflammation: Friend or foe of bovine reproduction? Animal Reproduction, 16, 539-547. doi: 10.21451/1984-3143-ar2019-0057

Cheng, Z., Oguejiofor, C. F., Swangchan-Uthai, T., Carr, S., \& Wathes, D. C. (2015). Relationships between Circulating Urea Concentrations and Endometrial Function in Postpartum dairy cows. Animals, 5(3), 748-773. doi: 10.3390/ani5030382

Cui, L., Wang, H., Ding, Y. et al. (2019). Changes in the blood routine, biochemical indexes and the pro-inflammatory cytokine expressions of peripheral leukocytes in postpartum dairy cows with metritis. BMC Vet Res, 15, 157. doi: 10.1186/s12917-019-1912-y 
Drift, S., Houweling, M., Schonewille, J., Tielens, A., \& Jorritsma, R. (2012). Protein and fat mobilization and associations with serum $\beta$ hydroxybutyrate concentrations in dairy cows. Journal of dairy science, 95. 4911-4920. doi: 10.3168/jds.2011-4771

Gammoh, N. \& Rink, L. (2017). Zinc in Infection and Inflammation. Nutrients, 9. doi: 10.3390/nu9060624

Grymak, Y., Skoromna, O., Stadnytska, O., Sobolev, O., Gutyj, B., Shalovylo, S., Hachak, Y., Grabovska, O., Bushueva, I., Denys, G., Hudyma, V., Pakholkiv, N., Jarochovich, I., Nahirniak, T., Pavliv, O., Farionik, T., \& Bratyuk, V. (2020). Influence of "Thireomagnile" and "Thyrioton" preparations on the antioxidant status of pregnant cows. Ukrainian Journal of Ecology, 10(1), 122-126. doi: 10.15421/2020_19

Hussein, H. \& Bäumer, J., \& Staufenbiel, R. (2019). Validation of an automated assay for measurement of bovine plasma ceruloplasmin. Acta veterinaria Scandinavica, 34. doi: 10.1186/s13028-019-0470-4

Hussein, H., \& Staufenbiel, R. (2012). Variations in Copper Concentration and Ceruloplasmin Activity of Dairy Cows in Relation to Lactation Stages with Regard to Ceruloplasmin to Copper Ratios. Biological Trace Element Research, 146, 47-52. doi: 10.1007/s12011-011-9226-3

Jarosz, M., Olbert, M., Wyszogrodzka, G. et al. (2017). Antioxidant and anti-inflammatory effects of zinc. Zinc-dependent NF-kB signaling. Inflammopharmacol, 25, 11-24. doi: 10.1007/s10787-017-0309-4

Kowsar, R., Iranshahi, V., Sadeghi, N., \& Riasi, A. (2018). Urea influences amino acid turnover in bovine cumulus-oocyte complexes, cumulus cells and denuded oocytes, and affects in vitro fertilization outcome. Scientific Reports, 8, 12191. doi: 10.1038/s41598-018-30774-2.

Kulyaba, O., Stybel, V., Gutyj, B., Turko, I., Peleno, R., Turko, Ya., Golovach, P., Vishchur, V., Prijma, O., Mazur, I., Dutka, V., Todoriuk, V., Golub, O. Dmytriv, O., \& Oseredchuk, R. (2019). Effect of experimental fascioliasis on the protein synthesis function of cow liver. Ukrainian Journal of Ecology, 9(4), 612-615.

Liu, M. J., Bao, S., Napolitano, J. R., Burris, D. L., Yu, L., Tridandapani, S., \& Knoell, D. L. (2014). Zinc regulates the acute phase response and serum amyloid A production in response to sepsis through JAK-STAT3 signaling. PloS one, 9(4), e94934. doi: 10.1371/journal.pone.0094934

Mazur, N. P., Fedorovych, V. V., Fedorovych, E. I., Fedorovych, O. V., Bodnar, P. V., Gutyj, B. V., Kuziv, M. I., Kuziv, N. M., Orikhivskyi, T. V., Grabovska, O. S., Denys, H. H., Stakhiv, N. P., Hudyma, V. Yu., \& Pakholkiv, N. I. (2020). Effect of morphological and biochemical blood composition on milk yield in Simmental breed cows of different production types. Ukrainian Journal of Ecology, 10(2), 61-67.doi: 10.15421/2020_110

Osorio, J. S., Ji, P., Drackley, J. K., Luchini, D., Loor, J. J. (2013). Supplemental Smartamine M or MetaSmart during the transition period benefits postpartal cow performance and blood neutrophil function Journal of Dairy Science, 96(10), 6248-6263. doi: 10.3168/jds.2012-5790.

Pontes, G. C., Monteiro, P. L. Jr, Prata, A. B., et al. (2015). Effect of injectable vitamin E on incidence of retained fetal membranes and reproductive performance of dairy cows. Journal of Dairy Science, 98(4), 2437-2449. doi: 10.3168/jds.2014-8886

Raboisson, D., Albaaj, A., Nonne, G., \& Foucras, G. (2017). High urea and pregnancy or conception in dairy cows: A meta-analysis to define the appropriate urea threshold. Journal of Dairy Science, 100(9), 7581-7587. doi: 10.3168/jds.2016-12009

Roy, B., Brahma, B., Ghosh, S., Pankaj, P. K., \& Mandal, G. (2011). Evaluation of Milk Urea Concentration as Useful Indicator for Dairy Herd Management: A Review. Asian Journal of Animal and Veterinary Advances, 6, 1-19. doi: 10.3923/ajava.2011.1.19

Saha, S., Alam, M., Shamsuddin, M., \& Khatun, M. (2016). Effects of breed, management system, milk yield and body weight on onset of postpartum ovarian cyclicity in cows. Bangladesh Veterinarian, 32(1), 27-34. doi: 10.3329/bvet.v32i1.29254

Sahoo, A. (2020). Clinical Nutrition and Therapeutic Diets: New Opportunities in Farm Animal Practice. EC Veterinary Science, 5(4), $12-29$.

Slivinska, L. G., Shcherbatyy, A. R., Lukashchuk, B. O., \& Gutyj, B. V. (2020). The state of antioxidant protection system in cows under the influence of heavy metals. Regulatory Mechanisms in Biosystems, 11(2), 237-242. doi:10.15421/022035

Tóthová, C., Mudroň, P., \& Nagy, O. (2017). The electrophoretic pattern of serum proteins in dairy cows with inflammatory diseases. Acta veterinaria, 67, 178-190. doi: 10.1515/acve-2017-0016

Tóthová, C., Nagy, O., Nagyová V., \& Kováč, G. (2018). Serum protein electrophoretic pattern in dairy cows during the periparturient period. Journal of Applied Animal Research, 46(1), 33-38, doi: 10.1080/09712119.2016.1256293

Travetsky, M. O. (2016). Fertilization of cows with spontaneous manifestation and synchronization of estrus. Bulletin of Sumy National Agrarian University, 6(39), 210-216.

Wathes, D. C., Bourne, N., Cheng, Z., et al. (2007). Multiple correlation analyses of metabolic and endocrine profiles with fertility in primiparous and multiparous cows. Journal of Dairy Science, 90(3), 1310-1325. doi: 10.3168/jds.s0022-0302(07)71619-3

Zhao, C., Shu, S., Bai, Y. (2019). Plasma Protein Comparison between Dairy Cows with Inactive Ovaries and Estrus. Sci Rep, 9, 13709. doi: $10.1038 / \mathrm{s} 41598-019-49785-8$

Citation:

Kraevsky, A.Y., Sokoluk, V.M., Chekan, O.M., Travetsky, M.O., Ligomina, I.P. (2020). Homeostasis indicators in cows before ostrus synchronization and their influence on the fertilization rate. Ukrainian Journal of Ecology, 106), 112-117.

(c) $\mathbf{E Y}$ This work is licensed under a Creative Commons Attribution 4.0. License 